\title{
ICARE (Introduction, Connection, Application, Reflection, and Extension): Analysis of Effectiveness in Improving Student's Communication and Collaboration Ability
}

\author{
Ahmad Walid ${ }^{*}$, Rambat Nur Sasongko², Muhammad Kristiawan², Raden Gamal Tamrin Kusumah', \\ Meri Andaria ${ }^{2}$ \\ ${ }^{1}$ Department of Science Education, IAIN Bengkulu, Bengkulu, Indonesia \\ 2 Education Doctoral Study Program, Bengkulu University, Bengkulu, Indonesia
}

DOI: $10.29303 /$ jppipa.v7i3.685

\section{Article Info}

Received: March 15th, 2021

Revised: May 11th, 2021

Accepted: May 24th, 2021

\begin{abstract}
This study aims to analyze the effectiveness of the Introduction, Conection, Application, Reflection, and Extension (ICARE) learning model in order to improve students' communication and collaboration skills. This research method is quantitative research with a Quasi-Experiment Design approach. Data collection techniques used in this study were observation, tests and documentation. Collecting data in this study is a documentation technique. This method is used to obtain research data in the form of a list of student names, subject syllabus, even semester final exam questions grid, objective questions and even semester final exam answer keys. The ICARE learning model can improve students' communication skills and student collaboration skills. Each stage in the ICARE model leads students to complete knowledge. Complete knowledge with good skills can optimize students' communication and collaboration skills. Seeing the development of the learning model used with its modification and implementation taking place in such a complex and directed manner, the ICERE learning model is considered capable of being a solution that can be used in the learning process primarily to see communication and collaboration skills so that it has bargaining power as a solution in current learning.
\end{abstract}

Keywords: Effectiveness; ICARE; Communication Skills; Collaboration Ability

Citation: Walid, A., Sasongko, R., Kristiawan, M., Kusumah, R., \& Andaria, M. (2021). ICARE (Introduction, Connection, Application, Reflection, and Extension): Analysis of Effectiveness in Improving Student's Communication and Collaboration Ability. Jurnal Penelitian Pendidikan IPA, 7(3), 305-309. doi:https://doi.org/10.29303/ippipa.v7i3.685

\section{Introduction}

21st century learning requires everyone to learn and think, focusing on developing intellectual abilities so that they are able to adapt to the changes and developments of the times (Zhao et al., 2020). The outcome in 21st century learning is to have life and career skills, namely the ability to synthesize information, work as a team, to manage broadly and complexly, and be responsible to society and the environment (Cawdery \& Hirata, 2011).

Skills in technology, media and information (information, media, and technology skills) are the ability to recognize, find and see all information with technology and media so that it can be meaningful (Walid et al., 2019). While critical learning and innovation skills are the ability to clarify understanding of a problem so as to produce innovation and logical decisions (Vanclay, 2020). 
An innovative and logical learning process is one aspect that affects learning outcomes (Syafi'i et al., 2018). The learning process has been carried out optimally with various learning models which are expected to make maximum student learning outcomes as well (Sulfemi, 2019). The learning model is a conceptual framework that describes a systematic procedure for organizing learning experiences to achieve specific learning goals, and serves as a guide for teachers in planning teaching and learning activities. (Friani et al., 2017). Communication skills are one of the skills that are included in the 21 Century Skills and are even one of the skills a person must have when entering the world of education (Kusumah et al., 2020) . Communication is not only a soft skill but is also seen as one of the keys to facing challenges in the 21st century (Haryanti \& Suwarma, 2018).

Communication itself is a form of providing or receiving information (Setiawan, 2018). The learning model is one of the important components in learning (Nurdyansyah, 2018). An effective learning model will be very helpful in the learning process, so that learning objectives will be more easily achieved (Shadiq, 2009). The preparation of lesson materials/sessions for active learning uses a very simple framework in a learning system such as ICARE (Sapri et al., 2021). The ICARE system includes the five key elements of a good learning experience, which can be applied to children, students, young people and adults. (Mahdian et al., 2019). Therefore, the ICARE system is very good to be applied not only to training wherever it is carried out but also in the learning process at school. ICARE stands for: Introduction, Connection, Application, Reflection, and Extension (Dwijayani, 2018). ICARE covers five key elements of the learning experience for children, youth and adults (Nadhif, 2019) namely as follows: Introduction, Connection Application, Reflection, Extension.

Students have the opportunity to apply what they have learned using the ICARE learning model (Dwijayani, 2018). Introduction, in this section, educators provide a contextual understanding of the content of the lesson to students. In the section an explanation of the objectives of the lesson / session and what will be achieved should be given briefly and simply. Connection, learning is a series of activities that provide an output in the form of results. Therefore, the learning experience must be seen from what is already known. In the Connection stage, students are trained from the ability to connect knowledge with one another and are trained to build their knowledge so that they can develop higher skills, such as creative thinking skills and problem-solving skills. Application: This is the most important part of the lesson. Once participants have acquired new information or skills through the connecting stage, they must be given the opportunity to practice and apply this knowledge and skills. Students are asked questions in a real-world context that are open-ended to solve by using concepts that have been developed. Collaboration at this stage is needed (Wahyudin, 2010) (Triani et al., 2018). Reflection, this section is a summary of the lessons learned, while participants have the opportunity to reflect on what they have learned. The teacher's task is to assess the extent of success in learning (Mitrayani et al., 2018). Reflection or summary activities may involve group discussions where the teacher asks students to make presentations or to explain what the students have learned. Extension, because the time of the lesson/session is over, does not mean that all participants who have learned can automatically use what they have learned.

The activities of this section are activities in which the teacher carries out activities that the participants can do after the lesson has ended to strengthen and expand learning. (Desstya, 2014). In school, Extension activities are usually called homework (Krisnawati et al., 2014).

Seeing the development of the learning model used with modification and its implementation taking place in such a complex and directed manner, the ICERE learning model is considered capable of being a solution that can be used in the learning process primarily to see communication and collaboration skills so that it has bargaining power as a solution in current learning.

Research conducted by Dwijayani (2018) shows that learning tools developed with the ICERE model are able to help students construct a concept and problems that are given according to the student's life/environment (Dwijayani, 2018), In line with that Triani et al., (2018) the application of the ICARE learning model assisted by practicum can improve learning implementation, problem solving skills and student learning outcomes.

\section{Method}

This research method is quantitative research with a Quasi-Experiment Design approach. Data collection techniques used in this study were observation, tests and documentation (Wisudawati, 2014). The sample of this research is MI Plus Nur Rahma Bengkulu City. Data analysis techniques using data on the ability to communicate and collaborate with students were analyzed descriptively by looking at the percentage of student observation sheets that can be calculated using the percentage descriptive analysis technique. (Anas, 2011). Data collection techniques are methods that can be used by researchers to collect data 
(Arikunto, 2019). Collecting data in this study is a documentation technique. This method is used to obtain research data in the form of a list of student names, subject syllabus, even semester final exam questions grid, objective questions and answer keys.

\section{Result and Discussion}

This research was conducted in the even semester of the 2021/2022 school year. This research was conducted in classes IV A and IV B at MI Plus Nur Rahma Bengkulu City with a total of 25 students consisting of 12 boys and 13 girls. In this chapter, the researcher will discuss the results of students' communication skills and collaboration skills with ordinary learning methods and by using the Introduction, Connection, Application, Reflection, and Connection (ICARE) learning model in science subjects, this research was conducted in two meetings.

\section{Students' Communication Skills}

In general, communication can be defined as a process of delivering messages from a source to the recipient with the intention of influencing the recipient of the message. From the concept above, there are at least 2 things that interpret communication. First, communication is a process, namely an activity to achieve communication goals itself. Thus, the communication process occurs not by accident, but is designed and directed towards achieving goals. Second, in the communication process forever involves three important components, namely the source of the message, namely the person who will convey or communicate something, the message, namely everything that wants to be conveyed or communication material, and the recipient of the message, namely the person who will receive the information. These three components are basic components in the communication process.

Communication in learning can occur during discussion and question and answer. Good communication skills will make it easier for students to convey their ideas/opinions in class. Student communication data is taken when the learning process is in progress using an observation sheet. The data on the results of student communication in the control class and experimental class are shown in Table 1

Table 1. Student Communication Results Data in the Control Class and Experiment Class

\begin{tabular}{llllll}
\hline \multirow{2}{*}{ NO } & Observed aspects & \multicolumn{2}{l}{ Control Class } & \multicolumn{2}{c}{ Experiment Class } \\
\cline { 3 - 6 } & & $\begin{array}{l}\text { Average } \\
\text { aspect }(\%)\end{array}$ & Criteria & $\begin{array}{l}\text { Average } \\
\text { aspect (\%) }\end{array}$ & Criteria \\
\hline 1 & Eyes sight & 50 & Effective enough & 81 & Effective \\
2 & Submission of Information & 44 & Less of a role & 60 & Effective enough \\
3 & Asking or Responding to Questions & 40 & Less of a role & 77 & Effective \\
4 & Understanding the Content of the Material & 40 & Less of a role & 79 & Effective \\
Average & 43 & Effective enough & 74 & Effective \\
\hline
\end{tabular}

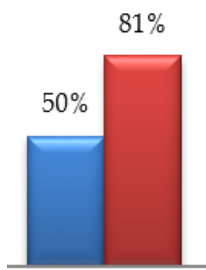

Eyes sight

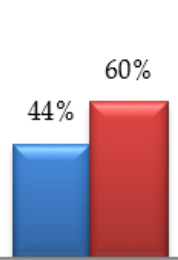

Submission of Information

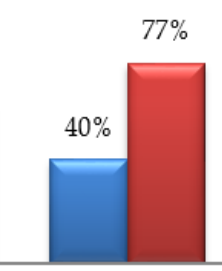

Asking or

Responding to therstanding Questions

\section{$79 \%$}

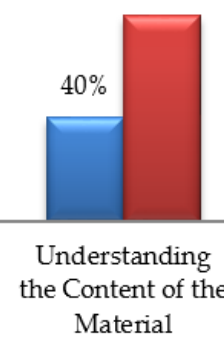

Figure 1. Improvement of Students' Communication Skills

\section{Student Collaboration Ability}

One of the 21st century skills that is important for every student to have is the ability to collaborate. Aspects that include the ability to collaborate are contained in the rubric, namely contributions, time management, problem solving, and working with other people.

$$
\square \text { Control Class } \square \text { Experiment Class }
$$

Table 2. Data on Student Collaboration Results in the Control Class and Experiment Class

\begin{tabular}{|c|c|c|c|c|c|}
\hline \multirow{2}{*}{$\mathrm{NO}$} & \multirow{2}{*}{ Observed aspects } & \multicolumn{2}{|l|}{ Control Class } & \multicolumn{2}{|l|}{ Experiment Class } \\
\hline & & Average aspect (\%) & Criteria & Average aspect $(\%)$ & Criteria \\
\hline 1 & Contribution & 40 & Less of a role & 68 & Effective \\
\hline 2 & Time Management & 35 & Less of a role & 70 & Effective enough \\
\hline 3 & Problem Solver & 38 & Less of a role & 68 & Effective \\
\hline 4 & Work with other people & 50 & Effective enough & 78 & Effective \\
\hline \multicolumn{2}{|c|}{ Average } & 41 & Less of a role & 70 & Effective \\
\hline
\end{tabular}




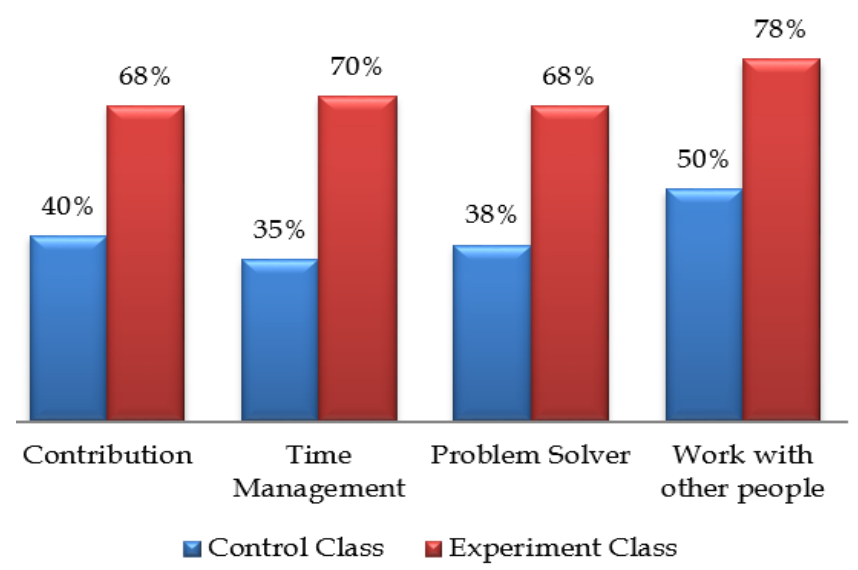

Figure 2. Increasing Student Collaboration Ability

Based on the results of research conducted on February 10, 2021, it shows that the ICARE learning model can be applied to science subjects at MI Plus Nur Rahma Bengkulu City, this can be seen after various learning activities are carried out. After the data is collected and calculated in the previous discussion, data on students' communication and collaboration skills can be seen based on Table 1, Table 2, Figure 1 and Figure 2, there are many improvements. We can see this increase from the mean and percentage obtained by the control class and the experimental class after participating in science learning. To make it easier to compare, it will be clearer when presented with the percentage table below:

Table 3. Percentage of Students' Communication and Collaboration Ability

\begin{tabular}{lllll}
\hline NO & Classes & \multicolumn{2}{l}{ Average Value } & Criteria \\
\cline { 3 - 4 } & & $\begin{array}{l}\text { Commu- } \\
\text { nication } \\
\text { Skills (\%) }\end{array}$ & $\begin{array}{l}\text { Collabora- } \\
\text { tion Ability } \\
(\%)\end{array}$ & \\
\hline 1 & Control & 43 & 41 & $\begin{array}{l}\text { Effective } \\
\text { enough }\end{array}$ \\
\hline 2 & Experiment & 74 & 70 & Effective \\
\hline
\end{tabular}

Based on the data above the average percentage of students' communication and collaboration skills, there has been a lot of improvement. The average communication ability between students was $43 \%$ in the control class and increased in the experimental class by $74 \%$. And the ability for collaboration between students was $41 \%$ in the control class and increased in the experimental class by $70 \%$. This shows that there is an increase and makes students understand and understand their duties and roles in the learning process. In general, the ICARE learning model carried out in this study is very helpful for students in thinking and solving a problem.

\section{Conclusion}

The conclusion that can be drawn from this study is that the ICARE learning model can improve students 'communication skills and students' collaboration skills. Each stage in the ICARE model leads students to complete knowledge. Complete knowledge with good skills can optimize students' communication and collaboration skills.

\section{References}

Anas, S. (2011). Pengantar evaluasi pendidikan. Jakarta: Rajawali Pers. [Indonesian]

Arikunto, S. (2019). Prosedur penelitian.

Cawdery, M., \& Hirata, B. (2011). Quick, cheap and easy instructional redesign. Thank you Google. ELearn: World Conference on E-Learning in Corporate, Government, Healthcare, and Higher Education, 1088.

Desstya, A. (2014). Kedudukan dan aplikasi pendidikan sains di sekolah dasar. Profesi Pendidikan Dasar, 1(2), 193-200. [Indonesian]

Dwijayani, N. M. (2018). Pembelajaran icare berbantuan permasalahan matematika realistik. Wahana Matematika dan Sains: Jurnal Matematika, Sains, dan Pembelajarannya. 12(1), 1-13. doi: http://dx.doi.org/10.23887/wms.v12i1.12714 [Indonesian]

Mahdian, M., Almubarak, A., \& Hikmah, N. (2019). Implementasi Model Pembelajaran ICARE (Introduction-Connect-Apply-Reflect-Extend) Terhadap Keterampilan Proses Sains Pada Materi Larutan Elektrolit Dan Non Elektrolit. Jurnal Penelitian Pendidikan IPA, 5(1). doi:https://doi.org/10.29303/jppipa.v5i1.184. [Indonesian]

Friani, I. F., Sulaiman, \& Mislinawati. (2017). Kendala Guru dalam Menerapkan Model Pembelajaran pada Pembelajaran Tematik berdasarkan Kurikulum 2013 di SD Negeri 2 Kota Banda Aceh. Jurnal Ilmiah Pendidikan Guru Sekolah Dasar FKIP Unsyiah, 2(1), 88-97. [Indonesian]

Haryanti, A., \& Suwarma, I.R. (2018). Profil Keterampilan Komunikasi Siswa Smp Dalam Pembelajaran Ipa Berbasis Stem. WaPFi (Wahana Pendidikan Fisika), 3(1), 49. doi: https://doi.org/10.17509/wapfi.v3i1.10940

Krisnawati, P. Y., Sugihartini, N., Kesiman, M. W. A., \& Wahyuni, D. S. (2014). Penerapan Model Pembelajaran Icare (Introduction Connection Application Reflection Extention) Untuk Meningkatkan Hasil Belajar Teknologi Informasi Dan Komunkasi (TIK)(Studi Kasus: Siswa Kelas VIII. 3 SMP Laboratorium Undiksha Singaraja Tahun Ajaran 2013-2014). KARMAPATI 
(Kumpulan Artikel Mahasiswa Pendidikan Teknik Informatika), 3(1), 89-95. doi: http://dx.doi.org/10.23887/karmapati.v3i1.19750 [Indonesian]

Kusumah, R. G. T., Walid, A., Sugiharta, I., Putra, E. P., Wicaksono, I., \& Erfan, M. (2020). Construction of High School Chemistry Module, Based on Problem-based Learning (PBL) on Salt Hydrolysis Material for Gifted Students. Journal of Physics: Conference Series, 1467, 12047. doi: https://doi.org/10.1088/17426596/1467/1/012047

Mitrayani, M., Hidayat, S., \& Novitasari, N. (2018). Pengaruh Model Pembelajaran Learning Cycle 7e Terhadap Hasil Belajar Siswa Pada Materi Keanekaragaman Hayati Kelas X Mia Di SMA Negeri 10 Palembang. Bioedukasi, 9(1), 14-26. doi: http://dx.doi.org/10.24127/bioedukasi.v9i1.1378 [Indonesian]

Nadhif, M. (2019). Efektivitas Model Pembelajaran Introduce, Connect, Apply, Reflect, Extend Dan Explicit Instruction Pada Mata Pelajaran Simulasi Dan Komunikasi Digital Terhadap Hasil Belajar Siswa. Under Graduates thesis, UNNES. retreived from: http://lib.unnes.ac.id/id/eprint/34319 [Indonesian]

Nurdyansyah, N. (2018). Model Pembelajaran Berbasis Masalah Pada Pelajaran IPA Materi Komponen Ekosistem. Universitas Muhammadiyah Sidoarjo. retreived from: http://eprints.umsida.ac.id/id/eprint/1611 [Indonesian]

Sapri, J., Novitasari, N., Saregar, A., Topano, A., Walid, A., \& Kusumah, R. G. T. (2021). Construction Ethnoscience-Based Learning Environment Material in Scientific Knowledge. Journal of Physics: Conference Series, 1796(1), 12034.

Setiawan, D. (2018). Dampak Perkembangan Teknologi Informasi dan Komunikasi Terhadap Budaya Impact of Information Technology Development and Communication on Culture. JURNAL SIMBOLIKA: Research and Learning in Communication Study. 4(1), 62-72. doi: https://doi.org/10.31289/simbollika.v4i1.1474. [Indonesian]

Shadiq, F. (2009). Model-model pembelajaran matematika SMP. Yogyakarta: P4TK Matematika Depdiknas. [Indonesian]

Sulfemi, W. B. (2019). Model pembelajaran kooperatif mind mapping berbantu audio visual dalam meningkatkan minat, motivasi dan hasil belajar IPS. Jurnal PIPSI (Jurnal Pendidikan IPS Indonesia), 4(1), 13-19. doi: http://dx.doi.org/10.26737/jpipsi.v4i1.1204 [Indonesian]
Syafi'i, A., Marfiyanto, T., \& Rodiyah, S. K. (2018). Studi tentang prestasi belajar siswa dalam berbagai aspek dan faktor yang mempengaruhi. Jurnal Komunikasi Pendidikan, 2(2), 115-123. doi: https://doi.org/10.32585/jkp.v2i2.114. [Indonesian]

Triani, L., Wahyuni, S., Purwanti, E., Hudha, A., Fatmawati, D., \& Husamah, H. (2018). Pembelajaran I-CARE berbantuan praktikum: Peningkatan problem-solving skills dan hasil belajar siswa pada materi jaringan hewan. Jurnal Inovasi Pendidikan IPA, 4(2), 158-168. doi:https://doi.org/10.21831/jipi.v4i2.21826.

Vanclay, F. (2020). Reflections on Social Impact Assessment in the 21st century. Impact Assessment and Project Appraisal, 38(2), 126-131. doi: https:// doi.org/10.1080/14615517.2019.1685807

Wahyudin, D. (2010). Model pembelajaran ICARE pada kurikulum mata pelajaran TIK di SMP. Jurnal Penelitian Pendidikan, 11(1), 23-33. [Indonesian]

Walid, A., Sajidan, S., Ramli, M., \& Kusumah, R. G. T. (2019). Construction of The Assessment Concept to Measure Students' High Order Thinking Skills. Journal for the Education of Gifted Young Scientists, 7(2), 237-251. doi: https:// doi.org/10.17478/jegys.528180

Wisudawati, W. (2014). Asih dan Eka Sulistyowati. Metodologi Pembelajaran IPA, Jakarta: Bumi Aksara. [Indonesian]

Zhao, X., Young, O. R., Qi, Y., \& Guttman, D. (2020). Back to the future: Can Chinese doubling down and American muddling through fulfill 21st century needs for environmental governance? Environmental Policy and Governance, 30(2), 59-70. doi: https://doi.org/10.1002/eet.1884 